\title{
Family Environment as Perceived by Youth: Gender Base
}

\author{
Pinki Ninaniya*, Santosh Sangwan and Shanti Balda \\ Department of Human Development and Family Studies, CCS Haryana Agriculture \\ University, Hisar, Haryana, India \\ *Corresponding author
}

\section{A B S T R A C T}

\section{Keywords}

Adolescent, Family

Environment,

Behavior, Boys,

Girls

Article Info

Accepted:

10 March 2019

Available Online:

10 April 2019
The family is the basic unit of a society to attribute with biological functions. It is the institution responsible for maintaining and building relationships among family members as well as with the community. The present study has carried out in Hisar district of Haryana state. For the study 200 adolescent i.e. 100 male and 100 female were taken between the age group of 16-18 years. Family Environment Scale developed by Bhatia and Chadha (1993) was used to assess home environment of the adolescent. Results of the study revealed that significant differences were noted between cohesion, acceptance, caring and control aspects of family environment. Results further revealed that girls had more cohesion and control environment as compare to boys whereas boys received more acceptance and caring from their family as compare to their counterparts.

\section{Introduction}

Family is an enduring association of parent and off springs whose primary function are the socialization of the child and satisfaction of the members. Family plays an important role during adolescence. It is a primary group which requires "people who are intimate and have frequent face-to face contact with one another, have norms in common and share mutually enduring and extensive influences. Family cohesion (i.e., the emotional bonding among family members and the feeling of closeness) is expressed by feelings of belonging and acceptance within the family system (McKeown et al., 1997). Adolescent perceptions of low cohesion within their families were associated with heightened feelings of depression and reduced social acceptance (Wentzel and Feldman, 1996) Thus, family members as members of a primary group have extreme influence upon each other. Adolescence is an important developmental phase along the path to adulthood, years during which youth become increasingly independent from their families. Parents and other family members still play a critical role in the promotion of adolescents' well-being, by providing a positive support system within which youth can explore their changing identity. Positive relationships with parents, characterized by low conflict, high 
levels of support, and open communication, are especially important for teens as they navigate the physical and emotional changes of adolescence. Frequent parent-adolescent communication and positive identification with parents are associated with less drug use, including less drinking and smoking among teens. The effectiveness of family functioning in conditioning the children's personality and social development has an outstanding importance (Roelfse and Middleton, 1985). Similarly, adolescents who report that they have a good relationship with at least one parent are more likely to report good physical and mental health. Family arguments during adolescence are to be expected, and may even serve an important developmental purpose. However, teens that experience high levels of conflict with and/or low levels of support from their parents are more likely to engage in risk behaviours. Due to the rapid changes within the modern family, the home stills the most important factor in shaping the behaviour of youth. The family climate is significant as it has a far reaching effect on its every member through various experiences and conditions of the family. A healthy home atmosphere and the factors that produce it are very important influences on adolescent's outlook for life. Better the communication between parents and children and greater the marital consensus and better the behaviour outcomes for adolescent children (Farell and Barnes, 1993). Adolescents need love and support from parents at a time when lots of other things in their lives are changing. During this time family is still a secure emotional base where the child feels loved and accepted, no matter what's going on in the rest of his life. Family can build and support the child's confidence, self-belief, optimism and identity. Role of the family context in adolescent well-being goes beyond the importance of the direct relationship between a parent and a child. Effective family functioning defined by cohesion, expressiveness and high personal growth are related positively to peer relations and role compliance. The more cohesive a family, the better the individual family members to function, the better the communication between parents and children and greater the marital consensus and better the behaviour outcomes for adolescent children (Farell\& Barnes, 1993).

\section{Materials and Methods}

\section{Locale of the Study}

Hisar district of Haryana state was purposively selected to get the sample for present study.

\section{Selection of area}

A list of villages having Senior Secondary Schools was procured from the Education Department of Hisar District. From the list two villages i.e. Arya Nagar from block Hisar I and Dabra from block Hisar II were selected randomly. Further two government schools, one each from selected villages were taken randomly to draw the rural sample and similar procedure was followed for urban sample. Two schools, namely Campus Senior Secondary School and Thakur Das Bhargava Senior Secondary School, Hisar were selected randomly for urban sample.

\section{Sampling procedure}

The study was confined to young adolescents of class 11th and 12th in the age group 16-18 years from selected all four schools. From each school, 50 adolescents equally representing both the sex i.e. 25 girls and 25 boys were selected on random basis. Hence, a total of 200 adolescents constituted the sample for present investigation. 


\section{Instrument}

Family Environment Scale developed by Bhatia and Chadha (1993) was used to assess home environment of the adolescents and its eight aspects i.e. Cohesion, Expressiveness, Conflict, Acceptance and Caring, Activerecreational orientation, Independence, Organization, Control. This includes both positives as well as negatives items and scored as extremely agree, agree, undecided, disagree, strongly disagree. The maximum score for positive item is awarded is 5 and least is 1. In case of negative items the scoring procedure is to be reversed.

\section{Data Collection}

The data was collected personally on individual basis with the help of standardized tool. The class teachers of the selected class from different schools were given prior information for the data and time of visit.

\section{Statistical analysis}

Frequency distribution and percentages were used to interpret the data. Z-test test was used for calculating the differences between means of independent variables of two large samples.

\section{Results and Discussion}

\section{Gender wise perception of adolescents for family environment}

Data in table 1 exhibits the distribution of respondents for quality of family environment as per gender. Perusal of results revealed that out of total sample more than fifty percent of adolescents fall in average category of family environment in cohesion (65\%), expressiveness (67.5\%), conflict (60.5\%), acceptance and caring (67\%) active recreational orientation $(66.5 \%)$ independence
$(64.5 \%)$, organization (66\%) and control $(66.5 \%)$.

Turning towards the gender wise comparison it showed that boys had better quality of family environment as results showing higher percentages on different aspects of family environment like expressiveness (19\%), conflict (15\%), and acceptance and caring $(21 \%)$, active recreational orientation $(19 \%)$ and independence $(22 \%)$ than their counterparts. Whereas, girls scored high on organization (19\%) and control $(20 \%)$ aspects of family environment as compare to boys as they were found less organized and had less control of family on them.

Mean comparison of respondents for quality of family environment as per gender

Comparison emanated from quality of family environment as per gender is displayed in table 2. Results showed that there were significant differences exist between cohesion $\left(\mathrm{Z}=1.99^{*}\right)$ and acceptance and caring $\left(\mathrm{Z}=2.08^{*}\right)$ aspects of family environment and gender. Moving towards comparison of mean scores of girl and boys, draw attention that girls had more cohesion $(M=53.30)$ and control environment $(\mathrm{M}=15.04)$ as compare to boys as they had less cohesion $(\mathrm{M}=50.34)$ and control environment $(M=14.81)$ in their family. Turning towards acceptance and caring aspects of family environment, boys received more acceptance and caring $(\mathrm{M}=45.35)$ from their family as compare to their counterparts $(\mathrm{M}=42.95)$.

The child constantly interacts with the family and is invariably influenced by the entire environment that surrounds him. Each child needs a congenial atmosphere, as he is innocent, tender and delicate since birth and needs someone who can nourish them with love and care. 
The gender wise comparison showed that boys had better quality of family environment as results showing higher percentages on different aspects of family environment like expressiveness, conflict, acceptance and caring, active recreational orientation and independence whereas, girls scored high on organization and control aspects of family environment. Boys were found less organized and had less control of family on them.

Table.1 Perception of adolescents for their family environment

\begin{tabular}{|c|c|c|c|c|}
\hline $\begin{array}{l}\text { Sr. } \\
\text { no. }\end{array}$ & $\begin{array}{l}\text { Aspects of family } \\
\text { environment }\end{array}$ & $\begin{array}{c}\text { Boys } \\
\mathrm{n}=\mathbf{1 0 0}\end{array}$ & $\begin{array}{c}\text { Girls } \\
\mathrm{n}=100\end{array}$ & $\begin{array}{c}\text { Total } \\
\mathbf{N}=\mathbf{2 0 0}\end{array}$ \\
\hline 1 & \multicolumn{4}{|l|}{ Cohesion } \\
\hline & Low (45and below) & $17(17.0)$ & $23(10.0)$ & $40(20.0)$ \\
\hline & Average (46to 60) & $69(69.0)$ & $61(43.0)$ & $130(65.0)$ \\
\hline & High (61and above) & $14(14.0)$ & $16(57.0)$ & $30(15.0)$ \\
\hline \multirow[t]{4}{*}{2} & \multicolumn{4}{|l|}{ Expressiveness } \\
\hline & Low (27and below) & $11(11.0)$ & $20(13.0)$ & $31(15.5)$ \\
\hline & Average (28 to 39 ) & $70(70.0)$ & $65(18.0)$ & $135(67.5)$ \\
\hline & High (40 and above) & $19(19.0)$ & $15(15.0)$ & $34(17.0)$ \\
\hline \multirow[t]{4}{*}{3} & \multicolumn{4}{|l|}{ Conflict } \\
\hline & Low (37 and below) & $18(18.0)$ & $22(18.0)$ & $40(20.0)$ \\
\hline & Average (38 to 51 ) & $67(67.0)$ & $64(60.0)$ & $131(65.5)$ \\
\hline & High (52 and above) & $15(15.0)$ & $14(22.0)$ & $29(14.5)$ \\
\hline \multirow[t]{4}{*}{4} & \multicolumn{4}{|c|}{ Acceptance and caring } \\
\hline & Low (40 and below) & $09(9.0)$ & $23(08.0)$ & $32(16.0)$ \\
\hline & Average (41 to 56 ) & $70(70.0)$ & $64(37.0)$ & $134(67.0)$ \\
\hline & High (57 and above) & $21(21.0)$ & $13(55.0)$ & $34(17.0)$ \\
\hline \multirow[t]{4}{*}{5} & \multicolumn{4}{|c|}{ Active-recreational orientation } \\
\hline & Low (30 and below) & $10(10.0)$ & $15(15.0)$ & $27(13.5)$ \\
\hline & Average (31 to 40 ) & $71(71.0)$ & $68(68.0)$ & $139(66.5)$ \\
\hline & High (41 and above) & $19(19.0)$ & $17(17.0)$ & $34(17.0)$ \\
\hline \multirow[t]{4}{*}{6} & \multicolumn{4}{|l|}{ Independence } \\
\hline & Low (6 and below) & $09(09.0)$ & $27(27.0)$ & $36(18.0)$ \\
\hline & Average (7 to 9 ) & $69(69.0)$ & $60(60.0)$ & $129(64.5)$ \\
\hline & High (10 and above) & $22(22.0)$ & $13(13.0)$ & $35(17.5)$ \\
\hline \multirow[t]{4}{*}{7} & \multicolumn{4}{|l|}{ Organization } \\
\hline & Low (6 and below) & $26(26.0)$ & $11(11.0)$ & $37(18.5)$ \\
\hline & Average (7 to 9 ) & $62(62.0)$ & $70(70.0)$ & $132(66.0)$ \\
\hline & High (10 and above) & $12(12.0)$ & $19(19.0)$ & $31(15.5)$ \\
\hline \multirow[t]{4}{*}{8} & \multicolumn{4}{|l|}{ Control } \\
\hline & Low (13 and below) & $23(23.0)$ & 11(11.0) & $34(16.5)$ \\
\hline & Average (14 to 17$)$ & $64(64.0)$ & $69(69.0)$ & $133(66.5)$ \\
\hline & High (18 and above) & 13(13.0) & $20(20.0)$ & $33(14.0)$ \\
\hline
\end{tabular}

Note: Figures in parentheses indicate percentages 
Table.2 Comparison of respondents for quality of family environment on the basis of gender

\begin{tabular}{|c|l|c|c|c|}
\hline Sr.no. & $\begin{array}{l}\text { Aspects of family } \\
\text { environment }\end{array}$ & $\begin{array}{c}\text { Boys } \\
\text { Mean } \pm \text { SD }\end{array}$ & $\begin{array}{c}\text { Girls } \\
\text { Mean } \pm \text { SD }\end{array}$ & 'Z' value \\
\hline $\mathbf{1}$ & Cohesion & $50.34 \pm 8.17$ & $53.30 \pm 6.39$ & $1.99^{*}$ \\
\hline $\mathbf{2}$ & Expressiveness & $32.18 \pm 6.19$ & $32.19 \pm 4.07$ & 0.22 \\
\hline $\mathbf{3}$ & Conflict & $40.63 \pm 6.77$ & $40.65 \pm 6.23$ & 0.11 \\
\hline $\mathbf{4}$ & Acceptance and caring & $45.35 \pm 5.69$ & $42.95 \pm 6.41$ & $2.08^{*}$ \\
\hline $\mathbf{5}$ & $\begin{array}{l}\text { Active recreational } \\
\text { orientation }\end{array}$ & $28.03 \pm 4.59$ & $28.57 \pm 5.88$ & 1.49 \\
\hline $\mathbf{6}$ & Independence & $30.68 \pm 4.63$ & $31.76 \pm 4.38$ & 1.12 \\
\hline $\mathbf{7}$ & Organization & $8.36 \pm 2.49$ & $8.29 \pm 1.61$ & 0.61 \\
\hline $\mathbf{8}$ & Control & $14.81 \pm 3.31$ & $15.04 \pm 2.44$ & 0.50 \\
\hline
\end{tabular}

*Significant at $5 \%$ level of significance

Comparison emanated from quality of family environment and gender results showed that there were significant differences exist between cohesion and acceptance and caring aspects of family environment and gender. These findings are similar to previous findings of Mohanraj and Latha (2005) boys perceived more control i.e., they perceived that their family has set rules and emphasize on following rules in the family.

The boys are more sensitized than girls by control in the family. The result of Verma and Ghadially, (1985) supported with the earlier finding also that male children receive more independence and encouragement than females because of cultural roles assigned to both the sexes in adult life.

In conclusion, the result revealed that boys had better quality of family environment on different aspects like expressiveness, conflict, acceptance and caring, active recreational orientation and independence than their counterparts.

Whereas, girls scored high on organization and control aspects of family environment as compare to boys as they were found less organized and had less control of family on them.

\section{References}

Bhatia, H. and Chadha, N.K. 1993. Family environment scale (FES). Ankur Psychological Agency, 22/481, Indra Nagar, Lucknow.

Farell, M.P., and Branes, G.M. 1993 Family system and social support. A test of the effects of cohesion and adaptability on functioning of parents and adolescents. Journal of Marriage \& Family, 55,119132.

McKeown, R. E., Garrison, C. Z., Jackson, K. L., Cuffe, S. P., Addy, C. L., and Waller, J. L. (1997).Family structure and cohesion, and depressive symptoms in adolescents. Journal of Research on Adolescence, 7, 267-282.

Mohanraj, R. Latha, 2005. Perceived family environment in relationto adjustment and academic achievement. Journal of the Indian Academic of Applied Psychological, 31:18-23.

Roelfse, R. and Middleton, M. R. (1985).: A measure of psychosocial family health during adolescence. Journal of Adolescence, 8, 33-45.

Verma, R.K. and Ghadialy, R. 1985. Effect of mother's sex role attitude on needs for achievements and expectancy for 
success in children. Psychological Studies, 30 (1):1-4.

Wentzel, K. R., and Feldman, S. S. (1996).

Relations of cohesion and power in family dyads to social and emotional adjustment during early adolescence. Journal of Research on Adolescences, 2,225-245.

\section{How to cite this article:}

Pinki Ninaniya, Santosh Sangwan and Shanti Balda. 2019. Family Environment as Perceived by Youth: Gender Base. Int.J.Curr.Microbiol.App.Sci. 8(04): 900-905. doi: https://doi.org/10.20546/ijcmas.2019.804.103 